\title{
Faktor yang Berhubungan dengan Pemanfaatan Pelayanan Kesehatan Gigi dan Mulut di Puskesmas Karanganyar Purbalingga Jawa Tengah Studi tentang Faktor Pengetahuan, Pendidikan, Pekerjaan, Pendapatan, dan Aksesibilitas
}

\section{Sindiawani G. Radiani, ${ }^{1}$ Oedijani-Santoso, ${ }^{2}$ Yoghi B. Prabowo. ${ }^{2}$ Tira H. Skripsa ${ }^{1}$}

\author{
${ }^{1}$ Departemen Kedokteran Gigi Fakultas Kedokteran Universitas Diponegoro, Semarang, \\ Indonesia. \\ ${ }^{2}$ Departemen Kedokteran Fakultas Kedokteran, Universitas Diponegoro, Semarang, \\ Indonesia. \\ Email: tirahamdillahskripsa@lecturer.undip.ac.id \\ Disubmisi: 1 Juli 2021; direvisi: 29 Juli 2021; diterima: 31 Juli 2021
}

\begin{abstract}
Utilization of dental and oral health services cover the health service and the usage of facilities. This study was aimed to determine and to analyze the relationship between knowledge, education, income, occupation, and accessibility of dental care utilization and oral health services at Karanganyar health centers of Purbalingga. This was an analytical survey study with a cross sectional design. There were 185 respondents of the working area of Karanganyar health center selected by consecutive sampling. Data were collected by using a validated questionnaire. Data were analyzed by using chi-square test followed by logistic regression test. The results showed that there were $76.8 \%$ of respondents who used dental care and oral health services in the three last months before pandemic Covid-19; $35 \%$ of respondents had no work; $69.2 \%$ had low level of education; $81.21 \%$ had high level of knowledge; $83.2 \%$ had low income; and $85.1 \%$ clarified that the accessibility was not reachable. The chi-square test showed a significant correlation between levels of knowledge $(\mathrm{p}=0.02)$, income $(\mathrm{p}=0.04)$, education $(\mathrm{p}=0.012)$ and dental care utilization as well as oral health services. The logistic regression test showed that knowledge (OR=0.569 (95\%CI:0.358-0.903) was the most dominant correlated to dental care utilization and oral health services. In conclusion, levels of knowledge, income, and education had significant relationships with dental care utilization and oral health services at Karanganyar health center.
\end{abstract}

Keywords: knowledge; income; education; dental care utilization and oral health services

\begin{abstract}
Abstrak: Pemanfaatan pelayanan kesehatan gigi dan mulut mencakup pelayanan dan penggunaan fasilitas pelayanan kesehatan gigi dan mulut. Penelitian ini bertujuan untuk mengetahui dan menganalisis hubungan antara pengetahuan, pendapatan, pendidikan, pekerjaan, dan aksesibilitas terhadap pemanfaatan pelayanan kesehatan gigi dan mulut di Puskesmas Karanganyar Kabupaten Purbalingga. Jenis penelitian ialah survei analitik dengan desain potong lintang. Sampel penelitian ialah 185 masyarakat di wilayah kerja Puskesmas Karanganyar, dipilih secara consecutive sampling. Pengambilan data dilakukan dengan menggunakan kuisioner yang sudah divalidasi. Data dianalisis menggunakan uji chi-square dilanjutkan dengan uji regresi logistik. Hasil penelitian mendapatkan bahwa responden yang memanfaatkan pelayanan kesehatan gigi dan mulut tida bulan terakhir sebelum pandemi covid-19 sebanyak 76,8\%; tidak bekerja $35 \%$; pendidikan rendah $69,2 \%$; tingkat pengetahuan tinggi $81,1 \%$; pendapatan rendah $83,2 \%$; dan $85.1 \%$ menyatakan aksesibilitas tidak terjangkau. Hasil uji chi-square menunjukkan hubungan bermakna antara tingkat pengetahuan $(\mathrm{p}=0,02)$, pendapatan $(\mathrm{p}=0,04)$, pendidikan $(\mathrm{p}=0,012)$ terhadap pemanfaatan pelayanan kesehatan gigi dan mulut. Hasil uji regresi logistik menunjukkan bahwa faktor pengetahuan OR=0,569 (95\% CI:0,358-0,903) yang paling dominan berhubungan dengan pemanfaatan pelayanan kesehatan gigi dan mulut. Simpulan penelitian ini ialah tingkat pengetahuan, pendapatan, pendidikan memiliki hubungan bermakna dengan pemanfaatan pelayanan kesehatan gigi dan mulut di Puskesmas Karanganyar.

Kata kunci: pengetahuan; pendapatan; pendidikan; pemanfaatan pelayanan kesehatan gigi dan mulut
\end{abstract}




\section{PENDAHULUAN}

Kesehatan gigi dan mulut merupakan salah satu indikator kesehatan manusia secara keseluruhan dan kualitas seseorang. Berdasarkan riset kesehatan gigi dan mulut (Riskesdas) 2018 sebanyak 57,6\% penduduk mengalami masalah kesehatan gigi dan mulut dengan hanya terdapat $10,2 \%$ tenaga medis. Salah satu upaya untuk menanggulangi berbagai permasalahan kesehatan gigi dan mulut ialah dengan diberikannya pelayanan kesehatan gigi dan mulut. ${ }^{1,2}$

Upaya pelayanan kesehatan gigi dan mulut merupakan langkah awal penting dalam rangka memberikan pelayanan kesehatan yang berhubungan dengan kesehatan gigi dan mulut secara dasar yang cepat dan tepat, dengan tujuan permasalahan kesehatan masyarakat dapat diatasi. Pelayananan ini diberikan pada fasilitas kesehatan seperti rumah sakit, klinik dokter gigi, dan puskesmas. $^{3}$

Puskesmas adalah fasilitas pelayanan kesehatan yang menyelanggarakan upaya kesehatan masyarakat dan upaya kesehatan perseorangan tingkat pertama, dengan lebih mengutamakan upaya promotif dan preventif agar supaya mencapai derajat kesehatan masyarakat yang setinggi-tingginya. ${ }^{2}$

Pemanfaatan pelayanan kesehatan gigi dan mulut merupakan pemanfaatan atau penggunaan fasilitas pelayanan kesehatan gigi dan mulut dalam bentuk pelayanan maupun program kesehatan gigi dan mulut yang ditujukan kepada perorangan atau bersama, dengan tujuan memelihara kesehatan gigi dan mulut. Saat ini pemanfaatan pelayanan kesehatan gigi dan mulut telah banyak menimbulkan minat banyak peneliti. ${ }^{4,5}$

Puskesmas Karanganyar merupakan salah satu puskesmas yang memiliki poli gigi di Kabupaten Purbalingga. Puskesmas Karanganyar memiliki 13 desa yang menjadi wilayah kerjanya. Pada tahun 2016 dari 35.869 jiwa hanya terdapat 116 orang yang mengunjungi pelayanan kesehatan gigi dan mulut, kemudian pada tahun 2017 menurun menjadi 108 orang, dan pada tahun 2018 hanya 90 orang yang mengunjungi pelayanan kesehatan gigi dan mulut. Pada tahun 2019, dari 14.121 jiwa hanya 270 orang yang mengunjungi pelayanan kesehatan gigi dan mulut. Hal ini masih sangat jauh dari harapan mengingat hanya sekitar $6,5 \%$ masyarakat yang memanfaatkan pelayanan kesehatan gigi dan mulut. ${ }^{6-9}$

Penelitian sebelumnya yang dilakukan oleh Lutfiyya et $\mathrm{al}^{10}$ melaporkan bahwa faktor usia tidak berpengaruh terhadap pemanfaatan layanan kesehatan gigi dan mulut namun faktor aksesibilitas yang meliputi jarak dan tidak tersedianya transportasi, kurangnya tingkat kesadaran serta biaya perawatan gigi memengaruhi pemanfaatan pelayanan kesehatan gigi dan mulut. Faktor berupa ketidakmampuan finansial diketahui juga dapat memengaruhi masyarakat dalam mengakses pelayanan kesehatan gigi dan mulut karena biaya yang mahal dan tidak selalu tercakup asuransi, sedangkan faktor berupa adanya fasilitas kesehatan yang menyediakan layanan gigi dan mulut dan informasi keberadaan fasilitas kesehatan dinilai tidak memiliki pengaruh terhadap pelayanan kesehatan gigi dan mulut., ${ }^{5,10}$

Latar belakang ini merupakan bukti bahwa banyak faktor yang dapat memengaruhi pemanfaatan pelayanan kesehatan gigi dan mulut. Oleh karena itu penulis tertarik untuk meneliti faktor pemanfaatan pelayanan kesehatan gigi dan mulut yang meliputi tingkat pengetahuan, pendapatan, pendidikan, pekerjaan, dan aksesibilitas.

\section{METODE PENELITIAN}

Penelitian ini dilaksanakan di wilayah kerja Puskesmas Karanganyar Kabupaten Purbalingga pada bulan Maret hingga April 2021. Jenis penelitian ini ialah survei analitik dengan desain potong lintang. Populasi penelitian ini ialah seluruh masyarakat di wilayah kerja Puskesmas Karanganyar Kabupaten Purbalingga yaitu sebanyak 185 responden. Variabel yang diteliti yaitu tingkat pengetahuan, pekerjaan, pendapatan, dan aksesibilitas. Instrumen yang digunakan dalam penelitian ini yaitu kuisioner yang telah divalidasi. Penelitian ini telah mendapat rekomendasi dari Komisi Etik Penelitian Kesehatan (KEPK) dengan Nomor 48/EC/KEPK/FK-UNDIP/III/2021. 


\section{HASIL PENELITIAN}

Tabel 1 memperlihatkan karakteristik 185 responden penelitian yang terdiri dari 59 orang laki-laki $(31,9 \%)$ dan 126 orang perempuan $(68,1 \%)$. Berdasarkan usia, didapatkan responden terbanyak ialah yang berusia 40-49 tahun $(32,4 \%)$ dan yang paling sedikit ialah responden berusia 60 tahun ke atas $(11,9 \%)$. Berdasarkan pekerjaan, sebagian besar responden tidak bekerja $(35,1 \%)$ dan yang paling sedikit ialah PNS $(6,5 \%)$. Tingkat pendidikan responden terbanyak ialah pendidikan menengah $(65,4 \%)$ dan yang paling sedikit ialah memiliki pendidikan rendah $(3,8 \%)$. Sebagian besar responden memiliki tingkat pengetahuan tinggi $(54,1 \%)$, diikuti pengetahuan sedang $(37,8 \%)$ dan sisanya memiliki tingkat pengetahuan rendah $(8,1 \%)$. Distribusi aksesibilitas jumlah sampel jawaban terbanyak ialah tidak terjangkau $(85,9 \%)$. Jumlah responden yang memanfaatkan pelayanan kesehatan gigi dan mulut yaitu sebanyak 142 orang $(76,8 \%)$, dan sisanya 43 orang $(23,2 \%)$ tidak memanfaatkan pelayanan pelayanan kesehatan gigi dan mulut.

Tabel 1. Distribusi frekuensi karakteristik responden keseluruhan

\begin{tabular}{|c|c|c|}
\hline Variabel & Frekuensi & $\%$ \\
\hline \multicolumn{3}{|l|}{ Jenis kelamin } \\
\hline Laki-laki & 59 & $31,9 \%$ \\
\hline Perempuan & 126 & $68,1 \%$ \\
\hline \multicolumn{3}{|l|}{ Usia } \\
\hline $20-29$ & 31 & $16,8 \%$ \\
\hline $30-39$ & 34 & $18,4 \%$ \\
\hline $40-49$ & 60 & $32,4 \%$ \\
\hline $50-59$ & 38 & $20,5 \%$ \\
\hline 60 tahun keatas & 22 & $11,9 \%$ \\
\hline \multicolumn{3}{|l|}{ Pekerjaan } \\
\hline Tidak bekerja & 65 & $35,1 \%$ \\
\hline Petani & 38 & $20,5 \%$ \\
\hline Buruh & 16 & $8,6 \%$ \\
\hline Wiraswasta & 54 & $29,2 \%$ \\
\hline PNS & 12 & $6,5 \%$ \\
\hline \multicolumn{3}{|l|}{ Pendidikan } \\
\hline Rendah & 7 & $3,8 \%$ \\
\hline Menengah & 121 & $65,4 \%$ \\
\hline Tinggi & 57 & $30,8 \%$ \\
\hline \multicolumn{3}{|l|}{ Pengetahuan } \\
\hline Rendah & 15 & $8,1 \%$ \\
\hline Sedang & 70 & $37,8 \%$ \\
\hline Tinggi & 100 & $54,1 \%$ \\
\hline \multicolumn{3}{|l|}{ Pendapatan } \\
\hline Tidak berpenghasilan & 46 & $24,9 \%$ \\
\hline$<2.000 .000$ & 108 & $58,4 \%$ \\
\hline$>=2.000 .000$ & 31 & $16,8 \%$ \\
\hline \multicolumn{3}{|l|}{ Aksesibilitas } \\
\hline Terjangkau & 26 & $14,1 \%$ \\
\hline Tidak terjangkau & 159 & $85,1 \%$ \\
\hline \multicolumn{3}{|c|}{ Pelayanan kesehatan gigi dan mulut } \\
\hline Memanfaatkan & 142 & $76,8 \%$ \\
\hline Tidak memanfaatkan & 43 & $23,3 \%$ \\
\hline
\end{tabular}


Tabel 2 memperlihatkan hasil analisis chi-square yaitu untuk tingkat pengetahuan rendah dan pemanfaatan pelayanan kesehatan diperoleh sebanyak $20(10,81 \%)$ responden yang memanfaatkan pelayanan kesehatan gigi dan mulut; untuk tingkat pengetahuan sedang sebanyak $36(19,4 \%)$ responden yang memanfaatkan pelayanan kesehatan gigi dan mulut; dan untuk tingkat pengetahuan tinggi sebanyak $86(46,5 \%)$ responden yang memanfaatkan pelayanan kesehatan gigi dan mulut. Hasil uji statistik memperoleh nilai $\mathrm{p}=0,002$ yang menunjukkan terdapat hubungan bermakna antara pengetahuan dengan pemanfaatan pelayanan kesehatan gigi dan mulut di Puskesmas Karanganyar.

Tabel 3 memperlihatkan hasil analisis hubungan pendapatan dengan pemanfaatan pelayanan kesehatan gigi dan mulut. Responden yang tidak berpenghasilan dan memanfaatkan pelayanan kesehatan gigi dan mulut sebanyak 30 orang (16,2\%); responden dengan pendapatan $<2.000 .000$ dan memanfaatkan pelayanan kesehatan sebanyak $83(44,9 \%)$ orang; dan responden berpendapatan tinggi dan memanfaatkan pelayanan kesehatan sebanyak $29(15,7 \%)$. Hasil uji statistik mendapatkan nilai $\mathrm{p}=0,04$ yang berarti terdapat hubungan bermakna antara pendapatan dengan pemanfaatan pelayanan kesehatan gigi dan mulut di Puskesmas Karanganyar Kabupaten Purbalingga.

Tabel 4 memperlihatkan bahwa sebanyak tiga $(1,62 \%)$ responden berpendidikan rendah dan memanfaatkan pelayanan kesehatan; sebanyak $94(50,8 \%)$ responden berpendidikan menengah dan memanfaatkan pelayanan kesehatan gigi dan mulut; dan sebanyak 45 (24,32\%) responden berpendidikan tinggi dan memanfaatkan pelayanan kesehatan gigi dan mulut di Puskesmas Karanganyar. Hasil uji statistik mendapatkan nilai $\mathrm{p}=0,012$ yang berarti terdapat perbedaan proporsi kejadian antara responden yang memiliki pendidikan rendah dan responden yang berpendidikan tinggi dalam memanfaatkan pelayanan kesehatan gigi dan mulut di puskesmas Karanganyar Kabupaten Purbalingga.

Tabel 5 memperlihatkan $47(72,31 \%)$ responden yang tidak bekerja dan memanfaatkan pelayanan kesehatan dan $95(79,17 \%)$ responden yang bekerja dan memanfaatkan pelayanan kesehatan gigi dan mulut di Puskesmas Karanganyar. Hasil uji statistik memperoleh nilai $\mathrm{p}=0,191$ yang berarti tidak terdapat perbedaan proporsi antara responden yang bekerja dan tidak bekerja dalam pemanfaatan pelayanan kesehatan gigi dan mulut di Puskesmas Karanganyar.

Tabel 2. Hubungan tingkat pnegetahuan dengan pemanfaatan pelayanan kesehatan gigi dan mulut

\begin{tabular}{|c|c|c|c|c|c|}
\hline \multirow[t]{3}{*}{$\begin{array}{c}\text { Tingkat } \\
\text { pengetahuan }\end{array}$} & \multicolumn{4}{|c|}{$\begin{array}{l}\text { Pemanfaatan pelayanan } \\
\text { kesehatan gigi dan mulut }\end{array}$} & \multirow[t]{3}{*}{$\mathbf{p}$} \\
\hline & \multicolumn{2}{|c|}{ Ya } & \multicolumn{2}{|c|}{ Tidak } & \\
\hline & $\mathrm{N}$ & $\%$ & $\mathrm{~N}$ & $\%$ & \\
\hline Rendah & 20 & 10,8 & 15 & 8,11 & \\
\hline Sedang & 36 & 19,4 & 14 & 7,5 & 0,002 \\
\hline Tinggi & 86 & 46,5 & 14 & 7,5 & \\
\hline
\end{tabular}

Tabel 3. Hubungan antara pendapatan dengan pemanfaatan pelayanan kesehatan gigi dan mulut

\begin{tabular}{lcrrrr}
\hline \multicolumn{1}{c}{ Pendapatan } & \multicolumn{4}{c}{$\begin{array}{c}\text { Pemanfaatan pelayanan } \\
\text { kesehatan gigi dan mulut }\end{array}$} & p \\
& $\mathrm{N}$ & Ya & \multicolumn{2}{c}{ Tidak } & \\
& 30 & 16,2 & 16 & 8,65 & \\
\hline Tidak & & & & & \\
berpenghasilan & & & & & \\
$<2.000 .000$ & 83 & 44,9 & 25 & 13,5 & 0,004 \\
$>=2.000 .000$ & 29 & 15,7 & 2 & 1,08 & \\
\hline
\end{tabular}


Tabel 4. Hubungan pendidikan dengan pemanfaatan pelayanan kesehatan gigi dan mulut

\begin{tabular}{llrlll}
\hline \multicolumn{1}{c}{ Pendidikan } & \multicolumn{4}{c}{$\begin{array}{c}\text { Pemanfaatan pelayanan } \\
\text { kesehatan gigi dan mulut }\end{array}$} & p \\
& & Ya & \multicolumn{2}{c}{ Tidak } & \\
& $\mathrm{N}$ & $\%$ & $\mathrm{~N}$ & $\%$ & \\
\hline Rendah & 3 & 1,62 & 4 & 2,16 & \\
Menengah & 94 & 50,8 & 33 & 17,84 & 0,012 \\
Tinggi & 45 & 24,32 & 6 & 3,24 & \\
\hline
\end{tabular}

Tabel 5. Hubungan pekerjaan dengan pemanfaatan pelayanan kesehatan gigi dan mulut

\begin{tabular}{lccccc}
\hline Pekerjaan & \multicolumn{4}{c}{$\begin{array}{c}\text { Pemanfaatan pelayanan } \\
\text { kesehatan gigi dan mulut }\end{array}$} & p \\
& $\mathrm{N}$ & Ya & \multicolumn{2}{c}{ Tidak } & \\
& & & $\mathrm{N}$ & $\%$ & \\
\hline Tidak bekerja & 47 & 72,31 & 18 & 27,69 & 0,191 \\
Bekerja & 95 & 79,17 & 25 & 20,83 & \\
\hline
\end{tabular}

Tabel 6. Hubungan aksesibilitas dengan pemanfaatan pelayanan kesehatan gigi dan mulut

\begin{tabular}{llllll}
\hline \multicolumn{1}{c}{ Aksesibilitas } & \multicolumn{4}{c}{$\begin{array}{c}\text { Pemanfaatan pelayanan } \\
\text { kesehatan gigi dan mulut }\end{array}$} & p \\
& $\mathrm{N}$ & Ya & \multicolumn{2}{c}{ Tidak } & \\
& $\mathrm{N}$ & $\mathrm{N}$ & $\%$ & \\
\hline Terjangkau & 126 & 68,11 & 36 & 19,46 & 0,264 \\
Tidak terjangkau & 16 & 8,65 & 7 & 3,78 & \\
\hline
\end{tabular}

Tabel 6 memperlihatkan bahwa sebanyak $126(68,11 \%)$ responden yang menyatakan aksesibilitas terjangkau dan memanfaatkan pelayanan kesehatan gigi dan mulut di puskesmas, sedangkan $16 \quad(8,65 \%)$ responden menyatakan aksesibilitas tidak terjangkau namun memanfaatkan pelayanan kesehatan gigi dan mulut di Puskesmas Karanganyar. Hasil uji statistik memperoleh $\mathrm{p}=0,264$ yang berarti tidak terdapat perbedaan proporsi antara responden yang menyatakan aksesibilitas terjangkau dan responden yang menyatakan aksesibilitas tidak terjangkau dalam memanfaatkan pelayanan kesehatan gigi dan mulut di Puskesmas Karanganyar.

Tabel 7 memperlihatkan hasil analisis uji regresi logistik yaitu responden yang memiliki tingkat pengetahuan tinggi berpeluang 0,5 kali lebih memanfaatkan pelayanan kesehatan gigi dan mulut dibandingkan responden selain pendidikan tinggi. Pada populasi, dengan derajat kepercayaan $95 \%$, responden yang memiliki pengetahuan tinggi menurunkan peluang 0,3 kali tidak memanfaatkan pelayanan kesehatan dan meningkatkan 0,9 kali memanfaatkan pelayanan kesehatan gigi dan mulut. Nilai $\mathrm{p}=0,017$ menunjukkan terdapat perbedaan bermakna antara responden yang memiliki tingkat pengetahuan tinggi dan tingkat pengetahuan rendah di wilayah Puskesmas Karanganyar.

Responden yang memiliki pendapatan $>=2.000 .000$ dapat meningkatkan peluang memanfaatkan pelayanan kesehatan di puskesmas sebesar 1,8 kali. Pada populasi, dengan derajat kepercayaan $95 \%$, responden yang berpendapatan $>=2.000 .000$ dapat menurunkan peluang 0,9 kali tidak meman faatkan pelayanan kesehatan dan meningkatkan 3,1 kali peluang memanfaatkan pelayanan kesehatan gigi dan mulut di puskesmas. Nilai $\mathrm{p}=0,054$ menunjukkan tidak terdapat perbedaan bermakna antara responden yang tidak memiliki penghasilan, $<2.000 .000$, dan $>=2.000 .000$. 
Tabel 7. Hasil analisis uji regresi logistik

\begin{tabular}{lcccc}
\hline Karakteristik & Beta & P & OR & IK 95\% \\
\hline Pengetahuan & $-0,564$ & 0,017 & 0,569 & $0,358-0,903$ \\
Pendapatan & 0,567 & 0,054 & 1,762 & $0,989-3.140$ \\
Pendidikan & $-0,723$ & 0,090 & 0,485 & $0,210-1,121$ \\
Pekerjaan & $-0,731$ & 0,957 & 0,931 & $0,071-12,149$ \\
Aksesibilitas & $-0,100$ & 0,203 & 0,904 & $0,311-2,631$ \\
\hline
\end{tabular}

Responden dengan pendidikan tinggi dapat meningkatkan peluang sebesar 0,4 kali untuk memanfaatkan pelayanan kesehatan gigi dan mulut di puskesmas. Pada populasi dengan derajat kepercayaan $95 \%$, responden yang berpendidikan tinggi dapat menurunkan 0,2 kali peluang tidak memanfaatkan pelayanan kesehatan dan meningkatkan 1,1 kali peluang memanfaatkan pelayanan kesehatan gigi dan mulut. Nilai $\mathrm{p}=0,09$ menunjukkan tidak terdapat perbedaan bermakna antara responden yang berpendidikan tinggi dan rendah.

Responden yang bekerja dapat meningkatkan peluang 0,9 kali lebih memanfaatkan pelayanan kesehatan gigi dan mulut di puskesmas. Pada populasi, dengan derajat kepercayaan $95 \%$ responden yang bekerja dapat menurunkan 0,071 kali peluang tidak memanfaatkan pelayanan kesehatan dan meningkatkan peluang 12,1 kali memanfaatkan pelayanan kesehatan gigi dan mulut. Nilai $\mathrm{p}=0,957$ menunjukkan tidak terdapat perbedaan bermakna antara responden yang bekerja dan tidak bekerja.

Responden yang menyatakan aksesibilitas terjangkau menurunkan peluang memanfaatkan pelayanan kesehatan sebesar 0,9 kali. Pada populasi, dengan kepercayaan 95\% responden dengan aksesibilitas terjangkau dapat menurunkan peluang 0,3 kali untuk memanfaatkan pelayanan kesehatan dan meningkatkan 2,6 kali peluang untuk memanfaatkan pelayanan kesehatan gigi dan mulut dibandingkan responden dengan aksesibilitas tidak terjangkau. Nilai $\mathrm{p}=0,203$ menunjukan tidak terdapat perbedaan bermakna antara responden dengan aksesibilitas terjangkau dengan yang tidak terjangkau.

\section{BAHASAN}

Penelitian ini dilaksanakan untuk mengetahui dan menganalisis faktor yang berhubungan dengan pemanfaatan pelayanan kesehatan gigi dan mulut di Puskesmas Karanganyar Kabupaten Purbalingga. Pemanfaatan pelayanan kesehatan gigi dan mulut merupakan pemanfaatan atau penggunaan fasilitas pelayanan kesehatan gigi dan mulut dalam bentuk pelayanan maupun program kesehatan gigi dan mulut yang ditujukan kepada perorangan atau bersama, dengan tujuan memelihara kesehatan gigi dan mulut. ${ }^{4}$ Pemanfaatan pelayanan kesehatan dapat dipengaruhi oleh banyak faktor dalam penelitian ini. Penulis hanya menetapkan lima faktor yaitu tingkat pendidikan, tingkat pengetahuan, pendapatan, pekerjaan dan aksesibilitas.

Pendidikan kesehatan merupakan upaya atau pembelajaran kepada masyarakat dengan tujuan mendorong masyarakat agar memiliki keinginan menjaga serta meningkatkan taraf kesehatannya. ${ }^{11}$ Hasil penelitian ini menunjukkan sebanyak 121 responden $(65,4 \%)$ memiliki pendidikan menengah. Hal ini dimungkinkan karena sebagian responden hanya menyelesaikan pendidikan hingga tamat SLTP/MTS/SMP sehingga mayoritas tingkat pendidikan responden ialah menengah. Hasil uji statistik tingkat pendidikan memperoleh nilai $\mathrm{p}=0,012$ $(\mathrm{p}<0,05)$ yang berarti terdapat hubungan bermakna antara tingkat pendidikan dengan pemanfaatan pelayanan kesehatan gigi dan mulut. Hal ini didukung oleh hasil penelitian Amalia et $\mathrm{al}^{4}$ yang menyatakan bahwa tingkat pendidikan dapat memengaruhi pola pikir seseorang untuk mempertimbangkan pengambilan keputusan dalam memanfaatkan pelayanan kesehatan. Seseorang yang memiliki pendidikan menengah ke bawah 
ketika memiliki gangguan kesehatan akan segera meminta bantuan ke fasilitas kesehatan tanpa memiliki pertimbangan, sedangkan, seseorang yang memiliki tingkat pendidikan tinggi memiliki bermacam pertimbangan dalam mengambil keputusan seperti lebih memilih fasilitas kesehatan yang lebih tinggi seperti rumah sakit karena fasilitas yang komplit. ${ }^{4}$ Hasil penelitian ini sejalan dengan penelitian oleh Santoso et al $^{12}$ yang menyatakan bahwa pendidikan memiliki hubungan bermakna dengan pemanfaatan pelayanan kesehatan gigi dan mulut di Puskesmas Maccini Sawah Kota Makassar.

Pengetahuan kesehatan merupakan pengetahuan mengenai bagaimana cara seseorang dalam memelihara kesehatan, pengetahuan tentang fasilitas pelayanan kesehatan, dan pengetahuan untuk menghindari penyakit. ${ }^{13}$ Berdasarkan hasil penelitian didapatkan mayoritas responden yang memanfaatkan pelayanan kesehatan gigi dan mulut ialah responden yang memiliki tingkat pengetahuan tinggi. Hal ini sesuai dengan pernyataan Sarwono ${ }^{14}$ yaitu semakin tinggi pengetahuan individu mengenai pengetahuan kesehatan, maka semakin tinggi upaya yang dilakukan untuk melakukan perncegahan. Hasil penelitian ini sejalan dengan penelitian yang dilakukan oleh Luthfiyyah et $\mathrm{l}^{10}$ yang menyatakan terdapat hubungan bermakna antara pengetahuan dengan pemanfaatan pelayanan kesehatan gigi dan mulut. Hal ini dapat disebabkan karena seseorang yang memiliki pengetahuan mengenai kesehatan akan terdorong untuk memelihara kesehatanya, salah satunya dengan memanfaatkan pelayanan kesehatan gigi dan mulut. ${ }^{15}$

Pendapatan merupakan penghasilan dapat berupa uang yang bersifat regular dan diterima sebagai bayaran atas upaya yang dilakukan seseorang. Pendapatan memiliki peran penting dalam pemanfaatan pelayanan kesehatan gigi dan mulut. ${ }^{16}$ Berdasarkan hasil penelitian pendapatan memiliki hubungan yang bermakna $(\mathrm{p}=0,040)$ dengan pemanfaatan pelayanan kesehatan gigi dan mulut. Hasil penelitian ini selaras dengan penelitian yang dilakukan oleh Variani et al $^{17}$ yang menyatakan bahwa terdapat hubungan antara pendapatan dengan pemanfaatan pelayanan kesehatan gigi dan mulut karena bila seseorang memiliki pendapatan relatif tinggi maka ia akan cenderung memanfaatkan pelayanan kesehatan gigi dan mulut dibandingkan dengan yang memiliki pendapatan rendah. Namun, pada penelitian ini responden yang memanfaatkan pelayanan kesehatan tertinggi ialah responden yang memiliki pendapatan kurang dari Rp. 2.000.000. Hal ini kemungkinan karena adanya Badan Penyelenggara Jaminan Sosial sehingga banyak masyarakat yang memiliki pendapatan rendah merasa tidak terkendala biaya untuk memanfaatkan pelayanan kesehatan di puskesmas.

Aksesibilitas dapat berupa biaya yang harus dikeluarkan dan jarak yang harus ditempuh oleh seseorang untuk mendapatkan pelayanan kesehatan gigi dan mulut. Berdasarkan hasil penelitian didapatkan mayoritas responden menyatakan aksesibilitas terjangkau dan memanfaatkan pelayanan kesehatan gigi dan mulut. Hal ini sejalan dengan hasil penelitian Karman et al $^{18}$ yang menyatakan bahwa masyarakat yang memiliki aksesibilitas terjangkau cenderung lebih memanfaatkan pelayanan kesehatan karena mereka dapat dengan mudah mencapai fasilitas kesehatan dibandingkan responden yang menyatakan aksesibilitas tidak terjangkau. Terdapat 16 responden $(8,65 \%)$ yang menyatakan aksesibilitas tidak terjangkau dan memanfaatkan pelayanan kesehatan gigi dan mulut. Hal ini sejalan dengan penelitian oleh Variani et $\mathrm{al}^{17}$ yang menyatakan bahwa tidak terdapat hubungan bermakna dengan pemanfaatan pelayanan kesehatan gigi dan mulut karena meskipun akses terjangkau masih terdapat sebagian besar responden yang tidak memanfaatkan pelayanan kesehatan gigi dan sebaliknya. Selain itu, meskipun dari tempat tinggal responden tidak terdapat angkutan umum yang dapat langsung menuju Puskesmas Karanganyar, hal tersebut bukan menjadi masalah karena responden dapat menggunakan transportasi ojek maupun menggunakan kendaraan pribadi. ${ }^{19}$

Pekerjaan merupakan suatu kegiatan 
individu untuk menempatkan upaya selama waktu dan ruang tertentu, dengan atau tanpa imbalan. ${ }^{20}$ berdasarkan hasil penelitian didapatkan mayoritass responden yang memanfaatkan pelayanan kesehatan gigi dan mulut di puskesmas adalah responden yang bekerja/memiliki pekerjaan. Hal ini sesuai dengan teori Dever dalam penelitian Tampi et al $^{18}$ yang menyatakan bahwa pekerjaan merupakan salah satu faktor pendukung yang memengaruhi seseorang dalam memanfaatkan pelayanan kesehatan gigi dan mulut. Namun, hasil uji statistik chisquare mendapatkan nilai $\mathrm{p}>0,05$ yang berarti tidak terdapat hubungan bermakna antara pekerjaan dengan pemanfaatan pelayanan kesehatan gigi dan mulut di Puskesmas Karanganyar. Hasil penelitian ini selaras dengan penelitian milik Susilawati ${ }^{22}$ yang melaporkan bahwa tidak terdapat hubungan bermakna antara pekerjaan dengan pemanfaatan pelayanan kesehatan gigi dan mulut. Hal ini dapat disebabkan karena meskipun tidak bekerja banyak responden yang masih tetap memanfaatkan pelayanan kesehatan gigi dan mulut di Puskesmas Karanganyar.

Berdasarkan hasil analisis regresi logistik, didapatkan faktor pengetahuan merupakan faktor yang paling berhubungan dengan pemanfaatan pelayanan kesehatan gigi dan mulut di Puskesmas Karanganyar dengan nilai $p=0,017(p<0,05)$. Responden yang memiliki tingkat pengetahuan tinggi memiliki peluang 0,5 kali untuk lebih memanfaatkan pelayanan kesehatan gigi dan mulut di puskesmas dibandingkan responden selain tingkat pengetahuan tinggi. Hal ini sesuai dengan hasil penelitian ini yaitu mayoritas responden yang memanfaatkan pelayanan kesehatan ialah responden yang memiliki tingkat pengetahuan tinggi.

Keterbatasan penelitian ini ialah distribusi sampel yang tidak merata sehingga penelitian ini mungkin kurang adekuat untuk mewakili populasi yang ada. Selain itu terdapat variabel yang mungkin berpengaruh namun tidak diteliti seperti persepsi masyarakat terhadap kesehatan gigi dan mulut, tingkat kesadaran, dan lainya. Rasio umur tidak merata sehingga peneliti tidak dapat menganalisis hubungan jenis kelamin berdasarkan usianya. Juga terdapat kesulitan dalam pengumpulan data responden karena adanya pandemi covid-19 yang menyebabkan adanya pembatasan interaksi sehingga penulis harus sangat berhati-hati seperti menjaga jarak dan juga tidak berlama-lama dalam melakukan kunjungan ke kediaman responden untuk menanyakan lebih detail mengenai kuisioner,

\section{SIMPULAN}

Terdapat hubungan antara pendidikan, pendapatan, dan tingkat pengetahuan dengan pemanfaatan pelayanan kesehatan gigi dan mulut. Responden yang memiliki tingkat pendidikan rendah, pendapatan kurang dari Rp. 2.000.000,- atau tingkat pengetahuan tinggi lebih memanfaatkan pelayanan kesehatan gigi dan mulut di Puskesmas Karanganyar. Tidak terdapat hubungan antara pekerjaan dengan pemanfaatan pelayanan kesehatan gigi dan mulut. Faktor pengetahuan tinggi memiliki hubungan yang paling bermakna terhadap pemanfaatan pelayanan kesehatan gigi dan mulut.

\section{Konflik Kepentingan}

Penulis menyatakan tidak terdapat konflik kepentingan dalam penelitian ini

\section{DAFTAR PUSTAKA}

1. World Health Organization. Oral Health. 2020. [cited 20 November 2020]. Available from: https://www.who.int/news-room/ fact-sheets/detail/oral-health

2. Menkes RI. Peraturan Menteri Kesehatan Republik Indonesia Nomor 31 Tahun 2019 tentang Sistem Informasi Puskesmas

3. Peraturan Menteri Kesehatan Republik Indonesia nomor 89 tahun 2015 tentang upaya kesehatan gigi dan mulut.

4. Amalia L, Permatasari II, Khomsan A, Riyadi H, Herawati T, Nurdiani R. Pengetahuan, sikap, dan praktek gizi ibu terkait iodium dan pemilihan jenis garam rumah tangga di wilayah pegunungan Cianjur. Jurnal Gizi Pangan. 2015;10(2):132-40.

5. Tasya N, Ansriany P, Herwanda. Faktor-faktor yang berhubungan dengan pemanfaatan 
pelayanan kesehatan gigi dan mulut (RSGM) Universitas Syiah Kuala Banda Aceh. Journal Caninus Dentistry. 2016; 1(4):54-62.

6. Dinas Kesehatan Kabupaten Purbalingga. Profil Kesehatan Kabupaten Purbalingga Tahun 2016.

7. Dinas Kesehatan Kabupaten Purbalingga. Profil Kesehatan Kabupaten Purbalingga Tahun 2017.

8. Dinas Kesehatan Kabupaten Purbalingga. Profil Kesehatan Kabupaten Purbalingga Tahun 2018.

9. Dinas Kesehatan Kabupaten Purbalingga. Profil Kesehatan Kabupaten Purbalingga Tahun 2019.

10. Lutfiyya MN, Gross JA, Soffe B, Lipsky MS. Dental care utilization: examining the associations between health services deficits and not having a dental visit in past 12 months. BMC Public Health. 2019:19(265):2-13.

11. Notoatmodjo S. Ilmu Kesehatan Masyarakat, Prinsip-Prinsip Dasar. Jakarta: Rineka Cipta, 2010.

12. Santoso ACM, Bramantoro T, Nguyen MC, Bagoly Z, Nagy A. Factors affecting dental service utilisation in indonesia: a population-based multilevel analysis. Int J Environ Res Public Health. 2020; 17(15):1-11.

13. Ismawati E. Metode Penelitian Pendidikan Bahasa dan Sastra. Surakarta: Yuma Pustaka, 2011.

14. Sarwono SW, Eko AM. Psikologi Sosial. Jakarta: Salemba Humanika, 2017; p. 60-71.

15. Azikin SL, Multazam MA, Yusriani. Analisis faktor presdisposing terhadap kualitas kesehatan gigi dan mulut melalui pemanfaatan pelayanan kesehatan. Window of Public Health Journal. 2020;
1(4);302-9.

16. Notoatmodjo S. Pengantar Pendidikan Kesehatan dan Ilmu Perilaku Kesehatan, Yogyakarta: Andi Offset, 1993.

17. Variani R, Ayatullah MI. Faktor-faktor yang berhubungan dengan pemanfaatan pelayanan kesehatan gigi ibu hamil. Journal of Oral Health Care. 2020; 8(1);29-33.

18. Karman, Sakka A, Saptaputra KS. Faktorfaktor yang berhubungan dengan pemanfaatan pelayanan kesehatan bagi pesisir di Desa Bungin Permai Kecamatan Tinanggea Kabupaten Konawe Selatan tahun 2016. Jurnal Ilmiah Mahasiswa Kesehatan Masyarakat. 2016;1(3):4-8.

19. Hidana R, Shaputra R, Maryati H. Faktorfaktor yang berhubungan dengan pemanfaatan pelayanan kesehatan oleh pasien luar wilayah Puskesmas Tanah Sareal Kota Bogor tahun 2018. Promotor. 2018:1(2):105-14.

20. Wijianto, Ulfa IF. Pengaruh status sosial dan kondisi ekonomi keluarga terhadap motivasi bekerja bagi remaja awal (usia 12-16 tahun) di Kabupaten Ponorogo.[cited 2020 Aug 11]. Al Tijarah. 2016;2(2):193-4.

21. Tampi J, Adisti AR, Ardiansa AT. Hubungan antara pendidikan, pendapatan dan pekerjaan dengan pemanfaatan pelayanan kesehatan di Rumah Sakit Umum Daerah Manembo-Nembo Bitung 2015. Sam Ratulangi Journal of Public Health. 2016;5(1):2-16.

22. Susilawati, Damayanti NA. Karakteristik pasien dengan keputusan pembelian jasa layanan kesehatan gigi dan mulut. Jurnal Keperawatan Silampari. 2020;4(1);8391. 